\title{
KONTRIBUSI SEKTOR PERTANIAN DALAM PEREKONOMIAN DI KABUPATEN MINAHASA
}

\author{
Nomiles Bembok \\ Gene Henfried Meyer Kapantow \\ Leonardus Ricky Rengkung
}

\begin{tabular}{ll}
\hline Naskah diterima melalui Email agrisosioekonomi@unsrat.ac.id & : Minggu, 30 Agustus 2020 \\
Disetujui diterbitkan & : Senin, 21 September 2020 \\
\hline
\end{tabular}

\begin{abstract}
This study aims to determine the contribution of the agricultural sector to the economy in Minahasa Regency for the 2014-2018 period. This research was conducted from March to May 2020. The data collection method used secondary data, which was sourced from the Central Statistics Agency of Minahasa Regency, and other sources such as mass media, journals, and other literature that related to this research topic. The variable measured in this study is the Gross Regional Domestic Product (PDRB) of Minahasa Regency at Constant Prices (ADHK) in 2014-2018. Data analysis used descriptive analysis method by making tables and percentages to explain the contribution of the agricultural sector to the economy in Minahasa Regency for the 2014-2018 period. The results showed that the contribution of the agricultural sector to the economy of Minahasa Regency from 2014 to 2018 continued to decline, with an average decline of $0.60 \%$ per year. However, the agricultural sector is still the largest contributor to the economy of Minahasa District. ${ }^{*}$ prm ${ }^{*}$
\end{abstract}

Keywords: contributors, agricultural sector, economy

\begin{abstract}
ABSTRAK
Penelitian ini bertujuan untuk mengetahui kontribusi sektor pertanian dalam perkonomian di Kabupaten Minahasa untuk periode Tahun 2014-2018. Penelitian ini dilaksanakan pada bulan Maret sampai Mei 2020. Metode pengumpulan data menggunakan data sekunder, yang bersumber dari Badan Pusat Statistik Kabupaten Minahasa, dan sumber-sumber lain seperti media cetak, jurnal-jurnal, dan literatur-literatur lain yang terkait dengan penelitian ini. Variabel yang diukur dalam penelitian ini adalah Produk Domestik Regional Bruto (PDRB) Kabupaten Minahasa Atas Dasar Harga Konstan (ADHK) Tahun 2014-2018. Analisis data menggunakan metode analisis deskriptif kuantitatif dengan membuat tabel dan persentase untuk menjelaskan kontribusi sektor pertanian dalam perkonomian di Kabupaten Minahasa untuk periode Tahun 2014-2018. Hasil penelitian menunjukkan bahwa kontribusi sektor pertanian terhadap perekonomian Kabupaten Minahasa dari tahun 2014 sampai tahun 2018 terus menurun, dengan rata-rata penurunan sebesar $0,60 \%$ per tahun. Walaupun demikian, sektor pertanian masih merupakan kontributor terbesar dalam perekonomian Kabupaten Minahasa. *eprm*
\end{abstract}

Kata kunci : kontributor, sektor pertanian, ekonomi 


\section{PENDAHULUAN}

\section{Latar Belakang}

Pembangunan merupakan upaya perubahan secara terencana seluruh dimensi kehidupan menuju tatanan kehidupan yang lebih baik di masa mendatang. Pembangunan ekonomi merupakan salah satu aspek pembangunan yang penting baik dalam lingkup pusat maupun daerah. Pembangunan ekonomi daerah merupakan suatu proses di mana masyarakat mengelola sumber daya yang ada dan membentuk suatu pola kemitraan antara pemerintah daerah dan sektor swasta untuk menciptakan suatu lapangan kerja baru dan merangsang perkembangan ekonomi dalam wilayah tersebut (Arsyad, 1999).

Pembangunan pertanian merupakan suatu proses perubahan sosial. Implementasinya tidak hanya ditujukan untuk meningkatkan status dan kesejahteraan petani semata, tetapi sekaligus juga dimaksudkan untuk mengembangkan potensi sumberdaya manusia baik secara ekonomi, sosial, politik, budaya, lingkungan, maupun melalui perbaikan (improvement), pertumbuhan (growth) dan perubahan (change) (Iqbal dan Sudaryanto, 2008).

Pembangunan pertanian bukan hanya suatu proses atau kegiatan dalam menambah produksi pertanian, melainkan proses yang menghasilkan perubahan sosial baik nilai, norma, perilaku, taraf hidup masyarakat dan sebagainya. Demi mencapai pertumbuhan ekonomi yang baik dan meningkatkan kesejahteraan masyarakat yang lebih baik, khususnya pada petani.

Sektor pertanian mempunyai peran yang sangat strategis, disamping seba-gai sumber penghasil devisa yang besar, sektor pertanian juga merupakan sumber ekonomi bagi sebagian besar penduduk Indonesia, dan merupakan sektor yang paling banyak dalam penyerapan tenaga kerja. Pada umumnya sebagian besar adalah tenaga kerja tidak terdidik, tidak memiliki ketrampilan dan pendapatan yang tidak merata. Atas kondisi inilah yang menyebabkan bargaining power yang dimiliki oleh para petani kita sangat lemah, sehingga nilai jual dari produk juga sangat berpengaruh terhadap kondisi ini (Esther, 2015).
Potensi pertanian Indonesia yang besar namun pada kenyataannya sampai saat ini sebagian besar dari petani kita masih banyak yang termasuk golongan miskin.hal ini mengindikasikan bahwa pemerintah pada masa lalu bukan saja kurang memberdayakan petani tetapi juga terhadap sektor pertanian keseluruhan.

Pembangunan pertanian di masa yang akan datang tidak hanya dihadapkan untuk memecahkan masalah-masalah yang ada, namun juga dihadapkan pula pada tantangan untuk menghadapi perubahan tatanan politik yang era demokratisasi yakni tuntutan otonomi daerah dan pemberdayaan petani. Di samping itu, dihadapkan pula pada tantangan untuk mengantisipasi perubahan tatanan dunia yang mengarah pada globalisasi dunia.

Pembangunan pertanian di Kabupeten Minahasa dianggap penting dari keseluruhan pembangunan Minahasa. Ada beberapa hal yang mendasari mengapa pembangunan pertanian di mempunyai peranan penting, antara lain: potensi sumber daya alam yang besar dan beragam, pangsa terhadap pendapatan nasional yang cukup besar, besarnya pangsa terhadap ekspor nasional, besarnya penduduk Minahasa yang menggantungkan hidupnya pada sektor ini, perannya dalam penyediaan pangan masyarakat dan menjadi basis pertumbuhan di pedesaan.

Indikator pembangunan ekonomi daerah tercermin dalam perkembangan Produk Domestik Regional Bruto (PDRB) dari tahun ke tahun. Perkembangan PDRB tersebut akan bermanfaat dalam perencanaan pembangunan. Pembangunan ekonomi di tingkat daerah maupun pusat terbagi menjadi sembilan sektor perekonomian. Sektor pertanian sendiri merupakan sektor yang memberikan kontribusi cukup besar dalam pembangunan perekonomian. Salah satu kabupaten yang mengandalkan pertanian sebagai sektor utama pembangunan adalah Kabupaten Minahasa.

\section{Konsep Pembangunan}

Pembangunan yang dilakukan difokuskan pada sebuah sektor ekonomi atau disebuah lokasi yang dinilai strategis. Dengan fokus pembangunan disuatu titik ini diharapkan hasil yang dihasilkan di titik yang menjadi pusat perhatian proses pembangunan akan dapat dirasakan oleh sektor ekonomi lain atau daerah lain yang berhubungan dengan titik tersebut baik secara langsung ataupun secara tidak langsung (Widodo dalam Potro, 2011). 
Menurut Djojohadikusumo dalam Potro (2011) pembangunan mempunyai arti lebih luas. Peningkatan produksi memang merupakan salah satu ciri pokok dalamproses pembangunan. Selain dari segi peningkatan produksi secara kuantitatif, proses pembangunan mencakup perubahan pada komposisi produksi, perubahan pada pola pembangunan (alokasi) sumberdaya produksi diantara sektor-sektor kegiatan ekonomi, perubahan pada pola pembangunan (distribusi) kekayaan dan pendapatan diantara berbagai golongan pelaku ekonomi, perubahan pada kerangka kelembagaan (institutional frame work) dalam kehidupan bermasyarakat.

Pembangunan adalah suatu kenyataan fisik dan suatu keadaan jiwa yang diupayakan caracaranya oleh masyarakat, melalui suatu kombinasi berbagai proses sosial ekonomi dan kelembagaan, untuk mencapai kehidupan yang lebih baik.

\section{Pembangunan Ekonomi}

Pembangunan ekonom merupakan suatu proses yang menyebabkan kenaikan pendapatan rill perkapita penduduk suatu negara dalam jangka panjang yang dsertai oleh perbaikan sistem kelembagaan (Maisaroh, 2017).

Pembangunan ekonomi memliki unsur unsur pokok dan sifat pokok sebagai berikut :

a. Suatu proses yang berarti perubahan yang terjadi secara kontinu.

b. Usaha untuk meningkatkan pendapatan perkapita.

c. Peningkatan pendapatan perkapita itu harus tetap berlangsung dalam jangka panjang.

d. Perbaikan sistem kelembagaan disegala bidang (misalnya politik, hukum sosial dan budaya). Sistem kelembagaan ini bisa ditinjau dari dua aspek yaitu aspek perbaikan dibdang aturan main (rule of the games), baik aturan formal maupun informal. Dan organisasi (players) yang mengimplementasikan aturan main tersebut.

Oleh karena itu, pembangunan ekonomi harus dipandang sebagai suatu proses agar pola keterkaitan dan saling mempengaruh antara faktorfaktor dalam pembangunan ekonomi dapat di amati dan di analisis. Dengan cara tersebut dapat diketahui runtutan pristiwa yang terjadi dan dampaknya pada peningkatan kegiatan ekonomi dan taraf kesejahteraan masyarakat dari satu tahap pembangunan ke tahap pembangunan berikutnya.

\section{Pembangunan Ekonomi Daerah}

Pembangunan ekonomi daerah perlu memberikan solusi jangka pendek dan jangka panjang terhadap isu-isu ekonomi daerah yang dihadapi, dan perlu mengkoreksi kebijakan yang keliru. Pembangunan ekonomi daerah merupakan bagian dari pembangunan daerah secara menyeluruh. Dua prinsip dasar pengembangan ekonomi daerah yang perlu diperhatikan adalah mengenali ekonomi wilayah dan merumuskan manajemen pembangunan daerah yang pro-bisnis (Darwanto dalam Potro, 2011).

\section{Syarat Pokok Pembangunan Pertanian}

Adapun syarat pokok pembangunan pertanian antara lain

a. Adanya pasar untuk hasil-hasil usahatani

b. Teknologi yang senantiasa berkembang

c. Tersedianya bahan-bahan dan alat-alat produksi secara lokal

d. Adanya perangsang produksi bagi petani

e. Tersedianya pengangkutan yang lancar dan kontinyu.

f. Pendidikan pembangunan

g. Kredit produksi

h. Kegiatan gotong royong petani

i. Perbaikan dan perluasan tanah pertanian

Pentingnya peran sektor pertanian dalam pembangunan ekonomi suatu daerah juga dikemukakan oleh Meier (1995), sebagai berikut:

a. Dengan mensuplai makanan pokok dan bahan baku bagi sektor lain dalam ekonomi yang berkembang

b. Dengan menyediakan surplus yang dapat diinvestasikan dari tabungan dan pajak untuk mendukung investasi pada sektor lain yang berkembang

c. Dengan membeli barang konsumsi dari sektor lain, sehingga akan meningkatkan permintaan dari penduduk perdesaan untuk produk dari sektor yang berkembang

d. Dengan menghapuskan kendala devisa melalui penerimaan devisa dengan ekspor atau dengan menabung devisa melalui substitusi impor.

Beberapa pertimbangan tentang pentingnya mengakselerasi Sektor pertanian di Indonesia dikemukakan oleh Simatupang (1997) Sebagai berikut:

1. Sektor pertanian masih tetap sebagai penyerap tenaga kerja, sehingga akselerasi pembangunan sektor pertanian akan membantu mengatasi masalah pengangguran. 
2. Sektor pertanian merupakan penopang utama perekonomian desa dimana sebagian besar penduduk berada. oleh karena itu, akselerasi pembangunan pertanian paling tepat untuk mendorong perekonomian desa dalam rangka meningkatkan pendapatan sebagian besar penduduk kabupaten Minahasa dan sekaligus pengentasan kemiskinan.

3. Sektor pertanian sebagai penghasil makanan pokok penduduk, sehingga dengan akselerasi pembangunan pertanian maka penyediaan pangan dapat terjamin. langkah ini penting untuk mengurangi ketergantungan pangan pada pasar.

4. Harga produk pertanian memiliki bobot yang besar dalam indeks harga konsumen, sehingga dinamikanya amat berpengaruh terhadap laju inflasi. oleh karena itu, akselerasi pembangunan pertanian akan membantu menjaga stabilitas.

5. Akselerasi pembangunan pertanian sangatlah penting dalam rangka mendorong ekspor dan mengurangi impor produk pertanian, sehingga dalam hal ini dapat membantu menjaga keseimbangan neraca pembayaran.

6. Akselerasi pembangunan pertanian mampu meningkatkan kinerja sektor industri. hal ini karena terdapat keterkaitan yang erat antara sektor pertanian dengan sektor industri yang meliputi keterkaitan produk, konsumsi dan investasi.

\section{Rumusan Masalah}

Rumusan masalah dalam penelitian ini adalah bagaimana kontribusi sektor pertanian dalam perkonomian di Kabupaten Minahasa Tahun 2014-2018?

\section{Tujuan Penelitian}

Penelitian ini bertujuan untuk mengetahui kontribusi sektor pertanian dalam perkonomian di Kabupaten Minahasa untuk periode Tahun 20142018.

\section{Manfaat Penelitian}

\section{Manfaat dari penelitian ini adalah}

a. Manfaat Akademis

Penelitian ini bermanfaat bagi penulis guna sebagai salah satu syarat penyelesaian studi, dan juga dapat menambah khasana keilmuan bagi peneliti dan pembaca mengenai kontribusi perekonomian di kabupaten Minahasa. b. Manfaat Praktis

Penelitian ini diharapkan dapat bermanfaat bagi masyarakat dan pemerintah Kabupaten Minahasa dalm menjaga peran dan stabilitas sektor pertanian terhadap perekonomian di Kabupaten Minahasa.

\section{METODE PENELITIAN}

\section{Tempat dan Waktu Penelitian}

Penelitian ini dilaksanakan di Kabupaten Minahasa, Provinsi Sulawesi Utara. Di laksaanakan pada bulan Maret sampai dengan bulan Mei 2020.

\section{Jenis Dan Sumber Data}

Jenis data yang digunakan dalam penelitian ini adalah data sekunder, yang bersumber dari Badan Pusat Statistik Kabupaten Minahasa, dan sumber-sumber lain seperti media cetak, jurnaljurnal, dan literatur-literatur lain yang terkait dengan penelitian ini.

\section{Metode Pengambilan Data}

Karena data yang digunakan dalam penelitian ini merupakan data sekunder, maka metode pengambilan data adalah dengan cara megumpulkan langsung data-data yang bersumber dari Badan Pusat Statistik (BPS) Kabupaten Minahasa melalui https://minahasa kab.bps.go.id, dan sumber-sumber lain seperti jurnal-jurnal dan literatur-literatur lain yang terkait dengan penelitian ini.

\section{Konsep Pengukuran Variabel}

Variabel yang diukur dalam penelitian ini adalah Produk Domestik Regional Bruto (PDRB) Kabupaten Minahasa Atas Dasar Harga Konstan (ADHK) Tahun 2014-2018.

\section{Analisis Data}

Teknik analisis yang digunakan dalam penelitian ini adalah analisis deskriptif kuantitatif dengan membuat tabel dan persentase untuk mengukur besarnya tingkat kontribusi sektor pertanian dalam perkonomian di Kabupaten Minahasa, dengan rumus:

Kontribusi Sektor Pertanian $=\frac{\text { PDRB Sektor Pertanian }}{\text { PDRB Total }} \times 100 \%$ 


\section{HASIL DAN PEMBAHASAN}

\section{Deskripsi Umum Lokasi Penelitian}

\section{Letak Geografi}

Kabupaten Minahasa memiliki luas wilayah sebesar $121,043.31$ ha yang terdiri dari 25 kecamatan. Kecamatan Tombariri/Tombariri Timur memiliki luas wilayah terbesar yaitu $15.840,89$ ha sedangkan Kecamatan Kawangkoaan memiliki luas wilayah terkecil yaitu 1.325,21 ha. Kabupaten Minahasa merupakan salah satu daerah yang ada di Sulawesi Utara. Letak daerah ini menurut garis lintang dan bujur adalah: $11^{\circ} 22^{\prime} 44^{\prime \prime} \mathrm{LU} /$ $124^{\circ} 33^{\prime}$ 52" BT ke $1^{\circ} 01^{\prime} \mathrm{LU} / 124^{\circ} 54^{\prime} 45^{\prime \prime}$ BT ke $125^{\circ} 04^{\prime} 21^{\prime \prime} \mathrm{BT} / 1^{\circ} 20^{\prime} 25^{\prime}$ " LU. Kabupaten Minahasa pada umumnya berbukit, bergunung, dan dataran yang agak luas, hanya sekitar Danau Tondano. Dataran tersebut dijumpai dalam wilayah Tondano, Romboken, Tompaso, Langowan, dan Kakas. Lereng beragam dari datar hingga sangat curam. Lereng-lereng yang sangat curam dijumpai didalam wilayah Kecamatan Kombi, Kecamatan Kakas, dan Kecamatan Langowan Selatan. Adapun batasbatasnya adalah sebagai berikut:

- Sebelah Utara berbatasan dengan Kabupaten Minahasa Utara;

- Sebelah Timur berbatasan dengan Laut Maluku;

- Sebelah Selatan berbatasan dengan Kabupaten Minahasa Tenggara;

- Sebelah Barat berbatasan dengan Laut Sulawesi;

- Di bagian tengah wilayah Kabupaten Minahasa terdapat wialayah Kota Tomohon.

Ibukota Kabupaten Minahasa adalah Tondano, berjarak sekitar $35 \mathrm{~km}$ dari Manado, ibukota Provinsi Sulawesi Utara. Luas Kabupaten Minahasa adalah 1.641,27 Km2 yang terdiri dari luas daratan adalah 1.094,88 $\mathrm{Km} 2$ dan luas perairan danau $46,54 \mathrm{Km} 2$ serta laut sebesar $599,85 \mathrm{Km} 2$.

\section{Kependudukan}

Berdasarkan konsep yang digunakan BPS, penduduk didefinisikan sebagai semua orang yang berdomisili di wilayah geografis Republik Indonesia selama enam bulan atau lebih dan atau mereka yang berdomisili kurang dari enam bulan tetapi bertujuan untuk menetap. Tabel 1 akan menunjukkan mengenai jumlah penduduk dan laju pertumbuhan penduduk Kabupaten Minahasa per tahun 2018-2019.

Tabel. 1. Jumlah Penduduk dan Laju Pertumbuhan Penduduk Kabupaten Minahasa Per Tahun 2018-2019

\begin{tabular}{|c|c|c|}
\hline Kecamatan & $\begin{array}{c}\text { Penduduk } \\
\text { (Jiwa) }\end{array}$ & $\begin{array}{c}\text { Laju Pertumbuhan } \\
\text { Penduduk Per Tahun } \\
\text { 2018-2019 }\end{array}$ \\
\hline Langowan Timur & 13,54 & 0,3 \\
\hline Langowan Barat & 16,90 & 2,4 \\
\hline Langowan Selatan & 8,27 & 4,2 \\
\hline Langowan Utara & 8,80 & 2,4 \\
\hline Tompaso & 7,51 & 2,2 \\
\hline Tompaso Barat & 9,07 & 3,0 \\
\hline Kawangkoan & 10,46 & 1,9 \\
\hline Kawangkoaan Barat & 8,90 & 4,0 \\
\hline Kawangkoaan Utara & 8,94 & 3,8 \\
\hline Sonder & 19,82 & 3,2 \\
\hline Tombariri & 18,36 & 1,1 \\
\hline Tombariri Timur & 10,49 & 4,1 \\
\hline Pineleng & 27,81 & 2,1 \\
\hline Tombulu & 17,76 & 0,8 \\
\hline Mandolang & 20,71 & 1,3 \\
\hline Tondano Barat & 20,84 & 1,9 \\
\hline Tondano Selatan & 17,34 & 0,1 \\
\hline Romboken & 12,60 & 2,0 \\
\hline Kakas & 12,63 & 0,2 \\
\hline Kakas Barat & 10,90 & 1,5 \\
\hline Lambean Timur & 8,51 & 3,8 \\
\hline Eris & 11,98 & $-0,6$ \\
\hline Kombi & 11,49 & $-0,6$ \\
\hline Tondano Timur & 15,62 & 1,2 \\
\hline Tondano Utara & 12,87 & 1,8 \\
\hline Minahasa & 342,11 & 1,5 \\
\hline
\end{tabular}

Sumber: Kabupaten Minahasa Dalam Angka 2020

Tabel 1 menunjukkan bahwa penduduk Kabupaten Minahasa berdasarkan Dinas Kependudukan dan Pencatatan Sipili tahun 2019 sebanyak 342,11 ribu jiwa dengan laju pertumbuhan penduduk per tahun 2018-2019 sebesar 1,51 persen. Laju pertumbuhan penduduk tertinggi terletak pada Kecamatan Langowan Selatan sebesar 4,2 persen dengan jumlah penduduk sebanyak 8,27 persen sedangkan laju pertumbuhan penduduk terendah per tahun 20182019 terletak pada Kecamatan Eris dan Kombi dengan persentase masing-masing sebesar $-0,6$ persen.

\section{Ketenagakerjaan}

Kondisi ketenagakerjaan erat kaitannya dengan kondisi ekonomi. Aktivitas ekonomi di Kabupaten Minahasa pada tahun 2018 mengalami percepatan dibandingkan dengan tahun sebelumnnya. Pada Tabel 2 dijelaskan mengenai jumlah angkatan kerja dan bukan angkatan kerja di Kabupaten Minahasa 2018. 
Tabel 2. Jumlah Angkatan Kerja dan Bukan Angkatan Kerja Kabupaten Minahasa, Tahun 2018

\begin{tabular}{lccc}
\multicolumn{4}{c}{ Kabupaten Minahasa, Tahun $\mathbf{2 0 1 8}$} \\
& \multicolumn{1}{c}{ Jenis Kelamin } & Jumlah \\
& Laki-laki & Perempuan & \\
\hline Angkatan Kerja & 107.979 & 66.054 & 174.024 \\
- Bekerja & 100.218 & 61.007 & 161.225 \\
- Pengangguran & 7.761 & 5.038 & 12.799 \\
Terbuka & & & \\
Bukan Angkatan Kerja & 26.623 & 62.593 & 89.216 \\
- Sekolah & 8.466 & 8.641 & 17.107 \\
- Mengurus Rumah Tangga & 8.532 & 47.012 & 55.544 \\
- Lainnya & 9.625 & 6.940 & 16.565 \\
\hline Sumber : Statistik Daerah Kabupaten Minahasa 2019
\end{tabular}

Tabel 2 menunjukkan bahwa jumlah angkatan kerja di Minahasa tahun 2018 sebanyak 174.024 orang yaitu yang bekerja sebanyak 161.225 dan pengangguran terbuka sebanyak 12.799 orang. Jumlah laki-laki yang bekerja dan yang termasuk pengangguran terbuka lebih mendominasi dari jumlah perempuan. Penduduk bukan angkatan kerja didominasi oleh penduduk yang hanya mengurus rumah tangga sebanyak 55.544 orang dan pada umumnya dilakukan oleh penduduk perempuan yaitu sebanyak 47.012 orang. Sedangkan penduduk yang bersekolah sebanyak 17.107 orang yang didominasi juga oleh penduduk perempuan sebanyak 8.641 orang. Dengan demikian, jumlah seluruh penduduk yang termasuk bukan angkatan kerja yaitu sebanyak 89.216 orang.

\section{Pendidikan}

Pendidikan merupakan hak asasi setiap warga negara Indonesia. Oleh sebab itu, setiap warga negara Indonesia berhak memperoleh pendidikan yang bermutu sesuai dengan minat dan bakat yang dimilikinya. Hak memperoleh pendidikan bagi setiap warga negara tidak memandang status sosial, status ekonomi, suku, etnis, agama, dan gender. Hal tersebut sudah tertuang dalam UUD 1945. Pada Tabel 3 dijelaksan mengenai Indikator Pendidikan Kabupaten Minahasa, Tahun 2016-2018.

Tabel 3. Indikator Pendidikan Kabupaten Minahasa, Tahun 2016-2018

\begin{tabular}{|c|c|c|c|}
\hline Uraian & 2016 & 2017 & 2018 \\
\hline \multicolumn{4}{|c|}{ Angka Partisipasi Sekolah } \\
\hline $7-12$ & 99,47 & 99,77 & 99,47 \\
\hline $13-15$ & 96,50 & 96,57 & 95,57 \\
\hline $16-18$ & 82,39 & 78,98 & 77,39 \\
\hline \multicolumn{4}{|c|}{ Kemampuan Baca Tulis } \\
\hline AMH & 99,887 & 99,84 & 99,94 \\
\hline Buta Huruf & 0,13 & 0,16 & 0,06 \\
\hline
\end{tabular}

Tabel 3 menunjukkan bahwa Angka Partisipasi Sekolah (APS) 2018 untuk usia wajib belajar 9 tahun mencapai 97,52 persen. Meski angka ini lebih dibanding tahun sebelumnya. Apabila ditelusuri lebih lanjut, APS usia 7-12 tahun mengalami sedikit penurunan dari 99,77 persen menjadi sekitar 99,47 persen, sedangkan APS untuk usia 13-15 tahun sedikit menurun, yaitu bergerak dari 96,57 persen menjadi 95,57 persen. Untul partisipasi sekolah pada jenjang di atasnya yaitu usia 16-18 tahun, pada tahun 2018 mengalami penurunan juga yaitu dari 99,87 menjadi 99,84 persen. Kemampuan baca tulis merupakan salah satu indikator keberhasilan bidang pendidikan.

Berdasarkan hasil Susenas, Angka Melek Huruf (AMH) sudah hampir sempurna, menjadi 99,94 persen. Dengan demikian pada tahun 2018 jumlah penduduk usia 10 tahun keatas yang masih buta huruf kian berkurang. Dari beberapa indikator di atas menunjukkan kualitas pendidikan di Kabupaten Minahasa cukup baik.

\section{Kesehatan}

Kualitas fisik penduduk dapat dilihat dari aspek derajat kesehatan penduduk. Derajat kesehatan penduduk yang baik menggambarkan bagaimana tingkat kesejahteraan penduduk tersebut. Kesehatan yang baik akan meningkatkan Indeks Pembangunan Manusia (IPM). Tidak ada artinya ekonomi dan pendidikan yang tinggi jika tidak dibarengi oleh kesehatan penduduknya. Pada Tabel 4 dijelaskan mengenai Statistik Kesehatan Kabupaten Minahasa, Tahun 2017-2018.

Tabel 4. Statitik Kesehatan Kabupaten Minahasa, Tahun

\begin{tabular}{lcc}
\multicolumn{1}{c}{$\mathbf{2 0 1 7 - 2 0 1 8}$ Uraian } & 2017 & 2018 \\
\hline \multicolumn{1}{c}{ Tempat Berobat Jalan : } & & \\
Rumah Sakit Pemerintah & 8,81 & 18,68 \\
Rumah Sakit Swasta & 4,32 & 11,96 \\
Praktek Dokter & 52,36 & 27,47 \\
Klinik/Praktek Dokter Bersama & 4,18 & 9,52 \\
Puskesmas/Pustu & 30,72 & 33,63 \\
UKBM & 2,04 & 0,75 \\
Praktek Pengobatan Tradisional & 1,85 & 0,33 \\
Lainnya & 0 & 0,42 \\
\hline Kepemilikan Jaminan Kesehatan : & & \\
Memiliki & 64,08 & 45,95 \\
Tidak Memiliki & 35,92 & 54,05 \\
\hline
\end{tabular}

Tabel 4 menunjukkan bahwa kepercayaan masyarakat terhadap layanan praktek dokter dan puskesmas guna memulihkan kondisi kesehatan masih tinggi, bahkan tidak sedikit masyarakat pengguna jasa rumah sakit maupun tenaga kesehatan yang kemudian beralih ke puskesmas. 
Banyaknya kunjungan ke puskesmas dan praktek dokter dikarenakan dekatnya fasilitas tersebut dari rumah pasien, tidak seperti rumah sakit yang hanya ada di pusat kota pada umumnya. Fasilitas yang paling sering dikunjungi pasien tahun 2018 adalah praktek dokter/bidan. Ada peralihan dari puskesmas ke praktek dokter, mungkin disebabkan praktek dokter lebih praktis dan waktu kunjungan lebih dapat diatur.

Namun demikian, puskesmas masih menjadi alternative kedua untuk berobat jalan. Kunjungan ke dokter praktek/bidan dan puskesmas mengalami peningkatan, terlihat dari naiknya persentase tempat berobat jalan pada tahun 2018. Sementara itu, persentase tempat berobat jalan di rumah sakit mengalami penurunan yang cukup signifikan. Sementara itu, penduduk Minahasa yang memiliki jaminan kesehatan mengalami peningkatan pada tahun 2017 yaitu sekitar 64,08 persen. Dengan kata lain setengah dari penduduk Minahasa telah memiliki jaminan kesehatan. Hal ini menunjukkan semakin membaiknya program kesehatan di Kabupaten Minahasa.

\section{Pertanian}

Pertanian merupakan salah satu sektor yang berkontibusi besar terhadap perekonomian yang ada di Indonesia, dan khususnya perekonomian Kabuapaten Minahasa. Selain berkontribusi terhadap perekonomian, sektor pertanian juga dapat menyediakan lapangan pekerjaan bagi masyarakat. Berdasarkan Badan Pusat Statistik (BPS), di Kabupaten Minahasa terdapat beberapa sub sektor yang berkontribusi terhadap perekonomian yang ada di Kabupaten Minahasa, yaitu sub sebktor horrtikultura, sub sektor peternakan, dan sub sektor perikanan.

\section{Tanaman sayuran}

Minahasa yang berada di wilayah cukup tinggi di atas permukaan laut, merupakan dataran yang subur. Cukup banyak tanaman sayuran hasil produksi di Minahasa. Produksi tanaman sayuran di Kabupaten Minahasa Tahun 2018, dapat dilihat pada Tabel 5.

Tabel 5. Produksi Tanaman Sayur Kabupaten Minahasa Tahun 2018

\begin{tabular}{lr}
\hline Uraian & Produksi (Kuintal) \\
\hline Tomat & 58.07 \\
Cabai & 44.060 \\
Kentang & 300 \\
Kubis & 3.562 \\
Bawang Merah & 13.808 \\
\hline Sumber: Statistik Daerah Kabupaten Minahasa 2019
\end{tabular}

Tabel 5 menunjukkan bahwa produksi terbesar tanaman sayuran selama tahun 2018 yaitu tomat sebanyak 58.072 kuintal, kemudian disusul tanaman cabai dengan produksi sebesar 44.060 kuintal. Sedangkan produksi tanaman sayuran tahun 2018 paling sedikit yaitu kentang dengan jumlah produksi sebesar 300 kuintal.

\section{Peternakan}

Peternakan merupakan salah satu sub sektor yang berkontribusi pada sektor pertanian yang ada di Kabupaten Minahasa. Pada Tabel 6 dijelaskan mengenai jumlah ternak di Kabupaten Minahasa, tahun 2018.

Tabel 6. Jumlah Ternak di Kabupaten Minahasa Tahun 2018

\begin{tabular}{lr}
\hline \multicolumn{1}{c}{ Uraian } & Jumlah (Ekor) \\
\hline Sapi Perah & 27 \\
Sapi Potong & 20.734 \\
Kuda & 3.150 \\
Kambing & 1.907 \\
Babi & 127.400 \\
Ayam Kampung & 735.500 \\
Ayam Petelur & 446.000 \\
Ayam Pedaging & 2.131 .200 \\
Itik/itik Manila & 81.421 \\
Merpati & 535 \\
Puyuh & 90.692
\end{tabular}

Sumber: Statistik Daerah Kabupaten Minahasa 2019

Tabel 6 menunjukkan bahwa populasi hewan ternak di Minahasa yang terbanyak adalah ayam pedaging sebanyak 2.131.200 ekor. Di wilayah Minahasa terdapat beberapa peternakan ayam pedaging ini. Ada di wilayah sekitaran Tondano dan Kawangkoan. Populasi ternak yang paling sedikit yaitu sapi perah yang hanya sebanyak 27 ekor. Sapi perah ini dibudidaya di wilayah Kecamatan Romboken.

\section{Produk Domestik Regional Bruto}

Produk Domestik Regional Bruto adalah jumlah nilai tambah bruto (gross value added) yang timbul dari seluruh sektor perekonomian di suatu wilayah dalam kurun waktu tertentu biasanya satu tahun ataupun dalam tiga bulan atau semesteran. Pada Tabel 7 dijelaskan mengenai Produk Domestik Regional Bruto Atas Dasar Harga Konstan (ADHK) Kabupaten Minahasa, Tahun 2014-2018. 
Tabel 7. Produk Domestik Regional Bruto Atas Dasar Harga Konstan (ADHK) Kabupaten Minahasa, Tahun 2014-2018

\begin{tabular}{|c|c|c|c|c|c|c|}
\hline \multirow[t]{2}{*}{ No } & \multirow[t]{2}{*}{ Kategori } & \multicolumn{5}{|c|}{$\begin{array}{c}\text { PDRB Kabupaten Minahasa Atas Dasar Harga } \\
\text { Konstan Menurut Lapangan Usaha (Rp) } \\
\text { Tahun 2014-2018 }\end{array}$} \\
\hline & & 2014 & 2015 & 2016 & 2017 & 2018 \\
\hline 1 & $\begin{array}{l}\text { Pertanian, } \\
\text { Kehutanan, } \\
\text { dan Perikanan }\end{array}$ & 2382245 & 250347 & 258008 & 266477 & 275174 \\
\hline 2 & $\begin{array}{l}\text { Pertambangan } \\
\text { dan Penggaliar }\end{array}$ & 595707 & 619919 & 663476 & 702093 & 746435 \\
\hline 3 & $\begin{array}{l}\text { Industri } \\
\text { Pengolahan }\end{array}$ & 755789 & 770012 & 779776 & 836128 & 902290 \\
\hline 4 & $\begin{array}{l}\text { Pengadaan } \\
\text { Listrik dan Gas }\end{array}$ & 10358 & 11298 & 13530 & 14882 & 15857 \\
\hline 5 & $\begin{array}{l}\text { Pengadaan Air } \\
\text { Pengelolaan } \\
\text { Sampah, } \\
\text { Limbah dan } \\
\text { Daur Ulang }\end{array}$ & 14216 & 14420 & 14751 & 14851 & 14967 \\
\hline 6 & Konstruksi & 1228027 & 1367801 & 1483558 & 1611858 & 1744175 \\
\hline 7 & $\begin{array}{l}\text { Perdagangan } \\
\text { Besar dan } \\
\text { Eceran; } \\
\text { Reparasi Mobi } \\
\text { dan Sepeda } \\
\text { Motor }\end{array}$ & 1022750 & 1067288 & 1138085 & 1224206 & 1316273 \\
\hline 8 & $\begin{array}{l}\text { Transportasi } \\
\text { dan } \\
\text { Pergudangan }\end{array}$ & 466647 & 504077 & 545230 & 571271 & 601868 \\
\hline 9 & $\begin{array}{l}\text { Penyediaan } \\
\text { Akomodasi } \\
\text { dan Makan } \\
\text { Minum }\end{array}$ & 88208 & 91600 & 97991 & 105113 & 116242 \\
\hline & $\begin{array}{l}\text { Informasi dan } \\
\text { Komunikasi }\end{array}$ & 181429 & 198316 & 218624 & 231934 & 247628 \\
\hline 11 & $\begin{array}{l}\text { Jasa } \\
\text { Keuangan dan } \\
\text { Asuransi }\end{array}$ & 208113 & 215501 & 261447 & 278728 & 273133 \\
\hline 12 & Real Estate & 397334 & 430770 & 459757 & 491955 & 527277 \\
\hline 13 & $\begin{array}{l}\text { Jasa } \\
\text { Perusahaan }\end{array}$ & 5395 & 5838 & 6302 & 6813 & 7373 \\
\hline 14 & $\begin{array}{l}\text { Administrasi } \\
\text { Pemerintahan, } \\
\text { Pertahanan, } \\
\text { dan Jaminan } \\
\text { Sosial Wajib }\end{array}$ & 726428 & 780807 & 828738 & 883803 & 942841 \\
\hline 15 & $\begin{array}{l}\text { Jasa } \\
\text { Pendidikan }\end{array}$ & 244849 & 258930 & 274993 & 290051 & 307598 \\
\hline 16 & $\begin{array}{l}\text { Jasa } \\
\text { Kesehatan dan } \\
\text { Kegiatan } \\
\text { Sosial }\end{array}$ & 335345 & 358236 & 387556 & 415583 & 447500 \\
\hline 17 & Jasa Lainnya & 143371 & 151183 & 162011 & 173399 & 197866 \\
\hline & PDRB & 8806209 & 9349470 & 99159091 & 05174411 & 1161063 \\
\hline
\end{tabular}

Tabel 7 menunjukkan bahwa Produk Domestik Regional Bruto Atas Dasar Harga Konstan (ADHK) Kabupaten Minahasa, Tahun 2014-2018 mengalami peningkatan tiap tahunnya, dengan rata-rata peningkatan sebesar Rp 588.713,5. Sumbangsi terbesar terletak pada sektor pertanian yang juga mengalami peningkatan tiap tahunnya walaupun hanya kecil, dengan rata-rata penigkatan sebesar Rp 92.374,25.

\section{Kontribusi Sektor Pertanian Terhadap Perekonomian Kabuapten Minahasa Tahun 2014-2018}

Sektor pertanian merupakan salah satu sektor penggerak perekonomian wilayah Kabupaten Minahasa. Untuk itu, perlu dilihat seberapa besar kontribusi yang diberikan oleh sektor pertanian terhadap PDRB Kabupaten Minahasa dalam mendorong pertumbuhan pereonomian wilayah Kabupaten Minahasa. Persentase kontribusi sektor pertanian terhadap PDRB Kabupaten Minahasa, Tahun 2014-2018 ditunjukkan dalam Tabel 8.

TabeI 8. Kontribusi Sektor Pertanian Terhadap PDRB Kabupaten Minahasa, Tahun 2014-2018 Atas Dasar Harga Konstan (ADHK)

\begin{tabular}{crrr}
\multicolumn{4}{c}{ Harga Konstan (ADHK) } \\
\hline Tahun & $\begin{array}{c}\text { PDRB Sektor } \\
\text { Pertanian (Rp) }\end{array}$ & $\begin{array}{r}\text { PDRB Seluruh } \\
\text { Sektor (Rp) }\end{array}$ & Kontribusi (\%) \\
\hline 2014 & 2.382 .245 & 8.806 .209 & 27,05 \\
2015 & 2.503 .476 & 9.349 .470 & 26,77 \\
2016 & 2.580 .084 & 9.915 .909 & 26,01 \\
2017 & 2.664 .774 & 10.517 .441 & 25,33 \\
2018 & 2.751 .742 & 11.161 .063 & 24,65 \\
\hline Sumber: Data Olahan 2020 & &
\end{tabular}

Tabel 8 menunjukkan bahwa kontribusi sektor pertanian terhadap PDRB Kabupaten Minahasa menunjukkan bahwa pada tahun 2014 persentasenya sebesar $27,05 \%$ kemudian mengalami penurunan pada tahun 2015 dengan persentase hanya sebesar 26,77\%. Menurunya kontribusi sektor pertanian terhadap perekonomian Kabupaten Minahasa terus berlanjut sampai pada tahun-tahun berikutnya dimana pada tahun 2016 kontribusi sektor pertanian terhadap perekonomian Kabupaten Minasaha sebesar 26,01\%, tahun 2017 turun menjadi $25,33 \%$, dan tahun 2018 kotribusi sektor pertanian terhadapa perekonomian Kabupaten Minahasa hanya sebesar 24,65\%. Penurunan ini di sebabkan adanya perkembangan dari sektorsektor lainnya dalam mendukung perekonomian Kabupaten Minahasa, serta banyaknya alih fungsi lahan-lahan pertanian yang dijadikan permukiman.

\section{Perkembangan Kontribusi Tiap-tiap Sektor dari Tahun 2014-2018}

Perkembangan kontribusi tiap-tiap sektor bertujuan untuk mengetahui trend perkembangan kontribusi tiap-tiap sektor perekonomian tiap tahunnya yang ada di Kabupaten Minahasa berdasarkan data Produk Domestik Regional Bruto 
(PDRB) Atas Dasar Harga Konstan (ADHK) Kabupaten Minahasa Tahun 2014-2018. Data perkembangan kontribusi tiap-tiap sektor perekonomian Kabupaten Minahasa Tahun 2014-2018 dilihat pada Tabel 9.

Tabel 9. Perkembangan Kontribusi Tiap-tiap Sektor Perekonomian Kaupaten Minahasa Tahun 2014-2018

\begin{tabular}{|c|c|c|c|c|c|c|}
\hline \multirow[t]{2}{*}{ No } & \multirow[t]{2}{*}{ Kategori } & \multicolumn{5}{|c|}{$\begin{array}{c}\text { Perkembangan Kontribusi Tiap-tiap } \\
\text { Sektor Perekonomian Kabupaten } \\
\text { Minahasa Tahun 2014-2018 (\%) }\end{array}$} \\
\hline & & 2014 & 2015 & 2016 & 2017 & 2018 \\
\hline 1 & $\begin{array}{l}\text { Pertanian, } \\
\text { Kehutanan, } \\
\text { dan Perikanan }\end{array}$ & 27,05 & 26,78 & 26,02 & 25,34 & 24,65 \\
\hline 2 & $\begin{array}{l}\text { Pertambangan } \\
\text { dan } \\
\text { Penggalian }\end{array}$ & 6,76 & 6,63 & 6,69 & 6,68 & 6,69 \\
\hline 3 & $\begin{array}{l}\text { Industri } \\
\text { Pengolahan }\end{array}$ & 8,58 & 8,24 & 7,86 & 7,95 & 8,08 \\
\hline 4 & $\begin{array}{l}\text { Pengadaan } \\
\text { Listrik dan Gas }\end{array}$ & 0,12 & 0,12 & 0,14 & 0,14 & 0,14 \\
\hline 5 & $\begin{array}{l}\text { Pengadaan Air, } \\
\text { Pengelolaan } \\
\text { Sampah, Limbah } \\
\text { dan Daur Ulang }\end{array}$ & 0,16 & 0,15 & 0,15 & 0,14 & 0,13 \\
\hline 6 & Konstruksi & 13,95 & 14,63 & 14,96 & 15,33 & 15,63 \\
\hline 7 & $\begin{array}{l}\text { Perdagangan } \\
\text { Besar dan } \\
\text { Eceran; Reparasi } \\
\text { Mobil dan } \\
\text { Sepeda Motor }\end{array}$ & 11,61 & 11,42 & 11,48 & 11,64 & 11,79 \\
\hline 8 & $\begin{array}{l}\text { Transportasi dan } \\
\text { Pergudangan }\end{array}$ & 5,30 & 5,39 & 5,50 & 5,43 & 5,39 \\
\hline 9 & $\begin{array}{l}\text { Penyediaan } \\
\text { Akomodasi dan } \\
\text { Makan Minum }\end{array}$ & 1,00 & 0,98 & 0,99 & 1,00 & 1,04 \\
\hline 10 & $\begin{array}{l}\text { Informasi dan } \\
\text { Komunikasi }\end{array}$ & 2,06 & 2,12 & 2,20 & 2,21 & 2,22 \\
\hline 11 & $\begin{array}{l}\text { Jasa Keuangan } \\
\text { dan Asuransi }\end{array}$ & 2,36 & 2,30 & 2,64 & 2,65 & 2,45 \\
\hline 12 & Real Estate & 4,51 & 4,61 & 4,64 & 4,68 & 4,72 \\
\hline 13 & Jasa Perusahaan & 0,06 & 0,06 & 0,06 & 0,06 & 0,07 \\
\hline 14 & $\begin{array}{l}\text { Administrasi } \\
\text { Pemerintahan, } \\
\text { Pertahanan, } \\
\text { dan Jaminan } \\
\text { Sosial Wajib }\end{array}$ & 8,25 & 8,35 & 8,36 & 8,40 & 8,45 \\
\hline 15 & Jasa Pendidikan & 2,78 & 2,77 & 2,77 & 2,76 & 2,76 \\
\hline 16 & $\begin{array}{l}\text { Jasa Kesehatan } \\
\text { dan Kegiatan } \\
\text { Sosial }\end{array}$ & 3,81 & 3,83 & 3,91 & 3,95 & 4,01 \\
\hline 17 & Jasa Lainnya & 1,63 & 1,62 & 1,63 & 1,65 & 1,77 \\
\hline
\end{tabular}

Tabel 9 menunjukkan bahwa perkembangan kontribusi tiap-tiap sektor perekonomian Kabupaten Minahasa tiap tahunnya dari Tahun 2014-2018 ada yang mengalami trend meningkat ditiap tahunnya, dan menurun ditiap tahunnya. Sektor-sektor yang mengalami trend peningkatan ditiap tahunnya dari tahun 2014-2018 dapat dilihat pada Tabel 10.
Tabel 10. Sektor-sektor Perekonomian Kabupaten Minahasa Tahun 2014-2018 Yang Mengalami Trend Peningkatan

\begin{tabular}{|c|c|c|c|c|c|}
\hline \multirow[t]{2}{*}{ Kategori } & \multicolumn{5}{|c|}{$\begin{array}{c}\text { Trend Peningkatan Sektor-sektor } \\
\text { Perekonomian Kabupaten Minahasa } \\
\text { Tahun 2014-2018 (\%) }\end{array}$} \\
\hline & 2014 & 2015 & 2016 & 2017 & 2018 \\
\hline Konstruksi & 13,95 & 14,63 & 14,96 & 15,33 & 15,63 \\
\hline Real Estate & 4,51 & 4,61 & 4,64 & 4,68 & 4,72 \\
\hline $\begin{array}{l}\text { Administrasi Pemerintahan, } \\
\text { Pertahanan dan Jaminan } \\
\text { Sosial Wajib }\end{array}$ & 8,25 & 8,35 & 8,36 & 8,4 & 8,45 \\
\hline $\begin{array}{l}\text { Jasa Kesehatan dan } \\
\text { Kegiatan Sosial }\end{array}$ & 3,81 & 3,83 & 3,91 & 3,95 & 4,01 \\
\hline
\end{tabular}

Tabel 10 menunjukkan bahwa sektor konstruksi merupakan sektor perekonomian Kabupaten Minahasa Tahun 2014-2018 yang trend peningkatannya paling tinggi dengan peningkatan kontribusi rata-rata sebesar $0,43 \%$, kemudian disusul oleh sektor real estate dengan peningkatan kontribusi rata-rata sebesar $0,05 \%$, sektor administrasi pemerintah, pertahanan dan jaminan sosial wajib dengan peningkatan kontribusi ratarata sebesar $0,05 \%$, dan sektor kesehatan dengan penigkatan kontribusi rata-rata sebesar $0,05 \%$. Sedangka sektor yang mengalami trend penurunan ditiap tahunnya dari tahun 2014-2018 akan dijelaskan pada Tabel 11.

Tabel 11. Sektor Perekonomian Kabupaten Minahasa Tahun 20142018 yang Mengalami Trend Penurunan

\begin{tabular}{lrllll}
\hline Kategori & \multicolumn{4}{c}{ Trend Penurunan Sektor Perekonomian } \\
\multicolumn{5}{c}{ Kabupaten Minahasa Tahun } & 2014-2018 (\%) \\
\hline & 2014 & 2015 & 2016 & 2017 & 2018 \\
\hline $\begin{array}{l}\text { Pertanian, } \\
\text { Kehutanan, dan } \\
\text { Perikanan }\end{array}$ & 27,05 & 26,77 & 26,01 & 25,33 & 24,65 \\
\hline
\end{tabular}

Tabel 11 menunjukkan bahwa sektor perekonomian Kabupaten Minahasa Tahun 2014-2018 yang mengalami trend penurunan ditiap tahunnya adalah sektor pertanian. Pada tahun 2015, kontibusi sektor pertanian, kehutanan, dan perikanan terhadap PDRB Kabupaten Minahasa adalah 27,05\% dan terus mengalami penurunan tiap tahun, dimana pada tahun 2018 menjadi 24,65\%. Ini berarti pada selang tahun 2014-2018 terjadi penurunan kontribusi sebesar $2,40 \%$, atau rata-rata sebesar $0,60 \%$ per tahun. Penurunan ini disebabkan oleh meningkatnya kontribusi sektor-sektor lain dalam perekonomian Kabupaten Minahasa. Faktor lain yang patut diduga menjadi penyebab adalah terjadinya pengalihfungsian lahan-lahan pertanian menjadi lahan pemukiman. 


\section{KESIMPULAN DAN SARAN}

\section{Kesimpulan}

Hasil penelitian menunjukkan bahwa kontribusi sektor pertanian terhadap perekonomian Kabupaten Minahasa dari tahun 2014 sampai tahun 2018 terus menurun, dengan rata-rata penurunan sebesar $0,60 \%$ per tahun. Walaupun demikian, sektor pertanian masih merupakan kontributor terbesar dalam perekonomian Kabupaten Minahasa.

\section{Saran}

Perlu dilakukan kajian lanjutan mengenai penyebab terjadinya penurunan kontribusi ini. Salah satu kemungkinan penyebab adalah terjadinya alih fungsi lahan pertanian menjadi lahan permukiman.

\section{DAFTAR PUSTAKA}

Arsyad,L.1999. Pengantar perencanaan dan pembangunan ekonomi daerah. BPFE UGM. Yogyakarta.

Esther, Aphrodite dan Lexy. 2015. Sektor Pertanian Merupakan Sektor Unggulan Terhadap Pembangunan Ekonomi Provinsi Maluku. Agriekonomika.
Iqbal \& Sudaryanto, 2008. Pembangunan Pertanian Indonesia. http://blogs unpad.ac.id/abysanilaras/2010/06/13/pe ntingny pembangunan pertanian-diindonesia. Di akses pada tanggal 28 Februari 2017.

Maisaroh, S. 2017. Analisis Peranan Dan Kontribusi Sektor Pertanian Terhadap Pertumbuhan Wilayah Dalam Perspektif Ekonomi Islam (Studi Pada Kabupaten Tulang Bawang) (Doctoral dissertation, UIN Raden Intan Lampung).

Meier, G.M. 1995. Leading Issues in Economic Development.Sixth Edition.Oxford University Press. New York.

Potro, B. S. (2011). Peran Sektor Pertanian Dalam Perekonomian Di Kabupaten Wonogiri.

Simatupang, P., 1997. Akselerasi Pembangunan Pertanian dan Pedesaan Melalui Strategi Keterkaitan Berspektrum Luas.Pusat Penelitian Sosial Ekonomi. Bogor. 